\title{
AdVERSE PoSSESSiON AS REPAIR MECHANISM: recent developments and further reflections
}

- Malcolm McKenzie PARK

who disputes the allegation that it was supervising his research that caused Professor Williamson to take early retirement.

Contribution (Chapter 10) to Abbas Rajabifard (ed), Towards a Spatially Enabled Society, Department of Geomatics, University of Melbourne, 2007, pp 139-144

\section{BACKGROUND and INTRODUCTION}

Ian Williamson came to the University of Melbourne as the Professor of Survey and Land Information in 1986. His professional education and training and much of his practicing experience was from NSW. This had the consequence that he came with the formed view that the NSW refusal to permit adverse possession was a limiting handicap and detrimental to the NSW system of registered land title (or Torrens system). In this he followed the view expressed by Justice Harvey of the NSW Supreme Court who in 1917 had deplored the omission of adverse possession from the NSW Torrens system.

That Professor Williamson viewed adverse possession as a boundary repair mechanism is demonstrated by his continued advocacy of its benefits after the introduction in 1979 of a limited form of adverse possession (related to whole parcels only) in NSW to allow for the problem of abandonment by the owner (or "disappeared" proprietor). As often expressed by Professor Williamson, in Victoria "what you see is what you get" while NSW required a prudent purchaser to commission an identification survey to confirm that the actual legal property being purchased coincided with that parcel as laid out on the ground (or occupation).

That adverse possession is an effective repair mechanism is alluded to by Jude Wallace and DW Lambden with the latter noting that whole parcel adverse possession repairs the register and is of interest only to the lawyer while part parcel adverse possession repairs the parcel description (or parcel boundary) and concerns the lawyer and the cadastral surveyor.

In the late 1990s Professor Williamson obtained research funding from LandVic and Land \& Property Information NSW to investigate part parcel adverse possession of 
Torrens registered title land with the consequence that I became a doctoral candidate under his supervision.

\section{PUBLIC vs PRIVATE CONVEYANCING}

The benefit provided by registered land title systems is founded upon the public nature of the transaction with the investigation and certification of title recorded in a public register and which provides for the enforcement of legal rights and protection for the community. For a long period it has been accepted wisdom that the advantages of the registered land title system over those of the system it replaced is best seen in the dichotomy of registered as opposed to unregistered conveyancing. Otherwise the dichotomy could be demonstrated by contrasting title registration with deeds registration. Further reflection since the submission of my dissertation leads me to the view that in fact the dichotomy is best exemplified by the public nature of the title registration system.

These reflections were brought about by the recognition that some of the European states have created a land title system based upon deeds registration but which provides reliable security of title and public confidence in its operation because the role of registration is performed by private practitioners licensed to exercise the public function of registration and maintaining the public register. In order to discharge that public function these practitioners must investigate and certify the title in question. To merely register only the transaction without investigation and certification is insufficient.

\section{PART PARCEL BOUNDARY REPAIR}

Of interest in this context is the recent introduction of registered land title in the Canadian province of Nova Scotia. That province's Land Registration Act 2001 came into effect in 2003 and, excepting "ripened" adverse possession of land outside the title registration system, prohibits the acquisition of title to registered title land. There is an exception for adjoining proprietors to acquire (by adverse possession) up to $20 \%$ of a neighbour's registered title lot as a means of resolving the "wandering boundary line". Of further interest, the allowance of part parcel adverse possession by an adjoining landowner is provided as an additional remedy to those provided by statutory encroachment, ie, Nova Scotia allows for both remedies as does Western Australia and the Canadian province of 
Alberta. Of further interest is the likelihood that the other Canadian Maritime provinces will adopt the Nova Scotia scheme.

This exception to the general prohibition against adverse possession is reminiscent of the pre-1980 Tasmanian provisions allowing for limited applications for land to be made by adjoining landholders. These pre-1980 Tasmanian and the 2003 Nova Scotia provisions support the proposition that part parcel adverse possession is widely used to "repair" boundaries of registered title land parcels where the occupations differ from the strict legal title.

In this context, it is of interest to note that NSW (which generally prohibits part parcel adverse possession) has recently allowed for part parcel adverse possession applications to be made in respect of those parts of disused rear access lanes abutting the applicant's land holding. The public interest served by this legislative amendment is that such rear access lanes are no longer required for the provision of municipal services and these disused lanes, while remaining open to public access, permit and foster criminal and other undesirable activities.

\section{HUMAN RIGHTS LEGISLATION}

After losing its legal action against the squatter in the English courts, the dispossessed proprietor has taken action in the European Court of Human Rights against the Government of the United Kingdom alleging that the English law relating to adverse possession offends against the Convention for the Protection of Human Rights and Fundamental Freedoms in that it permits a dispossessed proprietor to be deprived of its land without just compensation. Two preliminary hearings before the European Court have supported the applicant proprietor's case with the final determination expected shortly (as of February 2007).

The relevance of this case lies in the proposals for the Australian jurisdictions to enact similar provisions concerning human rights. Thus, it may be persuasive in those jurisdictions allowing for adverse possession. Of further relevance is that part parcel adverse possession applications are actually boundary disputes and are usually contested 
in that there is an "active" dispossessed proprietor challenging the squatter's acquisition of the proprietor's land. That is, boundary disputes are unlike land parcels abandoned by long disappeared proprietors of occupied whole parcels where there is no active registered proprietor with an interest in challenging the occupying squatter's application. [see J.A. Pye (Oxford) Ltd v The United Kingdom [2005] ECHR 92 (European Court of Human Rights; 15 November 2005) and Beaulane Properties v Palmer [2006] Ch 79.]

\section{IMPLIED RE-ENACTMENT}

In my January 2003 dissertation I argued that the Queensland Parliament had introduced, intentionally or otherwise, part parcel adverse possession with the passage of the 1994 Land Titles Act. In October of the same year the very issue was determined by the Chief Justice of Queensland who held that the 1994 Act had "impliedly re-enacted" the provisions of the legislative scheme as it existed immediately prior to the passage of the 1994 Act with the consequence that the statutory prohibition against part parcel adverse possession introduced into Queensland in 1952 was retained. Perhaps because of "an abundance of caution", the Queensland Parliament later passed the Natural Resources and Other Legislation Amendment Act 2005 which takes the issue beyond dispute.

In the Explanatory Notes to the 2005 legislation the Parliamentary Draftsperson has sought to explain the amendment as clarifying the law with regard to adverse possession "including effectively re-instating provisions from earlier legislation which were never intended to be repealed (and which may have been impliedly re-enacted) " and confirming "that an application may not relate to only part of a lot ...".

I merely make the observation that whereas courts of law are called upon to interpret statutes as passed by Parliament and sometimes infer an implied meaning to the words in the statute as chosen by the Parliamentary Draftsperson, it must be a rare occurrence for the Parliamentary Draftsperson to purport to interpret a statute by inferring an implied meaning to the words in the statute as chosen by the Parliamentary Draftsperson.

Otherwise, there can now be no doubt that the current Torrens system in operation in Queensland does not permit part parcel adverse possession.

[see Sherrard v Registrar of Titles [2004] Qd R 558 [2003] QSC 352 (Supreme Court of 
Queensland, de Jersey CJ, 16 October 2003) and Natural Resources and Other Legislation

Amendment Act 2005, section 81 replacing section 98 of the Land Titles Act 1994.]

\section{Post script:}

Since the publication of this book commemorating the career of Professor Williamson the European Court of Human Rights has made the final determination in the Pye v UK case wherein the Court dismissed the dispossessed registered proprietor's claim for relief against the United Kingdom because its laws permitted the squatter to obtain title against the registered proprietor: see Brendan Edgeworth, "Adverse Possession, Prescription and their reform in Australian Law", 15(1) Australian Property Law Journal 1 (2007) and Brendan Edgeworth, "Case Note: Adverse Possession and Human Rights", 15(1) Australian Property Law Journal 107 (2007); J.A. Pye (Oxford) Ltd and J.A. Pye (Oxford) Land Ltd v. The United Kingdom, [2007] ECHR 700 [URL:

http://cmiskp.echr.coe.int/tkp197/view.asp?action=html\&documentId=822955\&portal=hbk m\&source $=$ externalbydocnumber $\&$ table $=F 69 A 27 F D 8 F B 86142 B F 01 C 1166 D E A 398649$ ]

and the Press Release issued by the Registrar of the European Court of Human Rights Grand Chamber Judgment: J.A. Pye (Oxford) Ltd \& J.A. Pye (Oxford) Land Ltd v. United Kingdom, [2007] ECHR 705 [URL:

http://cmiskp.echr.coe.int/tkp197/view.asp?action=html\&documentId=822951\&portal=hbk $\underline{\text { m\&source }=\text { externalbydocnumber } \& \text { table }=F 69 A 27 F D 8 F B 86142 B F 01 C 1166 D E A 398649}$ ].

The Court's judgments are accessible on its Internet site (http://www.echr.coe.int).

\section{Biographical note}

A qualified civil engineer, Dr Park changed careers as a consequence of his mum informing all and sundry (including total strangers) that her son was 'the least civil person' she knew. After studying law and practising as a barrister for two decades he suffered a late mid-life crisis but was unable to afford the usual red sports car or to induce any bodacious blonde young thing to run away with him. Rejected and dejected, he allowed himself to be sucked into undertaking a $\mathrm{PhD}$ research degree in the Department of Geomatics involving the cross disciplines of land law and the public administration of the land title registry with particular regard to the resolution of land parcel boundary location discrepancies. The hard bound copy of his $\mathrm{PhD}$ thesis was deposited in the Bailleau Library in 2003 [Call No: UniM Baill T] with an AUS \$50 note inserted between pages 76 and 77. As of the last checking (21 September, 2007), the $\$ 50$ note remained undisturbed.

His thesis, The effect of adverse possession on part of a registered title land parcel (2003), is available at:

http://eprints.infodiv.unimelb.edu.au/archive/00000328/01/Park.pdf or http://www.geom.unimelb.edu.au/research/publications/MMP_PhD.pdf or http://en.scientificcommons.org/1850914

Contact: mmpark@unimelb.edu.au 


\section{University Library}

\section{- M M I N E R VA A gateway to Melbourne's research publications}

Minerva Access is the Institutional Repository of The University of Melbourne

Author/s:

Park, Malcolm McKenzie

Title:

Adverse possession as repair mechanism: recent developments and further reflections

Date:

2007

Citation:

Park, M. M. (2007). Adverse possession as repair mechanism: recent developments and further reflections. In A. Rajabifard (Ed.), Towards a spatially enabled society (pp. 139-144). Parkville: Department of Geomatics, University of Melbourne.

Publication Status:

Published

Persistent Link:

http://hdl.handle.net/11343/34794 